\begin{tabular}{|c|c|c|c|c|}
\hline JURNAL & \multirow{2}{*}{ VOLUME 3 } & \multirow{2}{*}{ NOMOR 1 } & HALAMAN 75-85 & $\begin{array}{l}\text { ISSN 2655-8823 }(p) \\
\text { ISSN 2656-1786 }(e)\end{array}$ \\
\hline
\end{tabular}

\title{
PERILAKU PELANGGARAN LALU LINTAS OLEH REMAJA DITINJAU DARI PERSPEKTIF KONSTRUKSI SOSIAL
}

\author{
Rahayu Nurfauziah \\ Prodi Ilmu Kesejahteraan Sosial, FISIP Universitas Padjadjaran \\ E-mail: rahayu19001@mail.unpad.ac.id \\ Hetty Krisnani \\ Pusat Studi CSR, Kewirausahaan Sosial dan Pemberdayaan Masyarakat FISIP Universitas Padjadjaran \\ E-mail: hetty.krisnani@unpad.ac.id
}

\begin{abstract}
ABSTRAK
Salah satu masalah utama dalam lalu lintas adalah kecelakaan lalu lintas yang menimbulkan korban jiwa dan kerugian material. Perilaku komunitas sangat menentukan dalam pelanggaran lalu lintas. Tujuan dari penelitian ini adalah untuk mengetahui atau menganalisis: (1) faktor penyebab terjadinya pelanggaran lalu lintas dan (2) strategi yang dilakukan oleh SATLANTAS dalam mengurangi pelanggaran lalu lintas sehingga tercapainya masyarakat patuh hukum. Metode yang digunakan yaitu metode deskiptif dengan pendekatan studi pustaka, dan teori yang digunakan adalah teori perspektif konstruksi sosial. Hasil penelitian menemukan bahwa: Penegakan hukum lalu lintas dalam rangka tercapainya masyarakat patuh hokum belum bekerja secara profesional dikarenakan penerapan hukum tidak diaksanakan sebagaimana mestinya, sikap penegak hokum yang belum profesional, serta sarana dan prasarana yang terbatas untuk mendukung terlaksananya penegakan hukum.
\end{abstract}

Kata kunci: perilaku, komunitas, dampak, pelanggaran, lalu lintas.

\section{PENDAHULUAN}

Latar belakang penelitian ini didasari pada perilaku masyarakat pengguna jalan baik pengemudi maupun para pejalan kaki terhadap rambu lalu lintas dalam berlalu lintas yang menimbulkan dampak terhadap keselamatan seseorang serta kerugian material dan non material.

Pelanggaran lalu lintas merupakan suatu tindakan yang diperbuat oleh seseorang yang sedang mengemudikan kendaraan umum atau kendaraan bermotor serta pejalan kaki yang bertentangan dengan peraturan perundang-undangan yang berlaku.

Masalah yang paling utama dalam berlalu-lintas yaitu kecelakaan lalu-lintas. Menurut Global Status Report on Road Safety (2013), sebanyak 1,24 juta korban meninggal tiap tahun di seluruh dunia dan 20-50 juta orang mengalami luka akibat kecelakaan lalu lintas. Di Indonesia pada kurun waktu 10 tahun terakhir, data menunjukkan telah merenggut korban jiwa rata-rata 10.000 per tahun, dimana sekitar
332 orang meninggal dunia dari 1000 kecelakaan yang terjadi. (Marka,2004).

Akibat dari kecelakaan lalu lintas selain menimbulkan korban jiwa juga menimbulkan kerugian materi yang mana diperkirakan mencapai 41,3 triliun rupiah yang sangat memprihatinkan. Apabila tidak segera dilakukan langkah-langkah strategis guna meningkatkan keselamatan dan kepatuhan hukum dalam lalu lintas masyarakat, maka akan menimbulkan daftar panjang korban jiwa dan kerugiana secara material. Peningkatan jumlah kendaraan bermotor di Indonesia juga tentunya sangat berpengaruh terhadap masalah lalu lintas secara umum. Sebagai contohnya peningkatan jumlah kendaraan bermotor pada tahun 2000 yakni 24.671.330 dan pada tahun 2003 berjumlah 32.774.299 yakni mengalami peningkatan sebanyak 8.100 .594 kendaraan. Peningkatan ini tidak diimbangi dengan penambahan panjang ruas jalan yang memadai.

Kecelakaan lalu lintas menurut UU No. 22 Tahun 2009 Pasal 1 ayat 24 adalah 


\begin{tabular}{|c|c|c|c|c|}
\hline JURNAL & \multirow{2}{*}{ VOLUME 3} & \multirow{2}{*}{ NOMOR 1 } & HALAMAN 75-85 & $\begin{array}{l}\text { ISSN 2655-8823 }(p) \\
\text { ISSN 2656-1786 }(e)\end{array}$ \\
KOLABORASI RESOLUSI KONFLIK & HOLN
\end{tabular}

suatu peristiwa di jalan yang tidak diduga dan tidak disengaja yang melibatkan kendaraan dengan atau tanpa pengguna jalan lain yang mengakibatkan korban manusia dan atau kerugian harta benda. Lalu lintas merupakan pergerakan kendaraan dan orang di ruang lalu lintas jalan (Dephub, 2009). Kecelakaan merupakan suatu kejadian tidak terjadi secara kebetulan melainkan disertai suatu penyebab yang dapat dicari tahu guna melakukan tindakan preventif. Dampak yang ditimbulkan oleh kecelakaan yaitu berupa dampak ringan samapi berat berupa materi maupun non materi (Sumakmur, 2009).

Selain itu, kecelakaan lalu lintas juga dapat disebabkan oleh beberapa hal seperti : pengemudi kendaraan yang buruk, kendaraan besar atau kecil yang sembarangan parkir, ketidakteratur antara transportasi yang besar dan yang kecil atau tidak sesuai dengan luas jalan, pejalan kaki yang kurang hati-hati daam berjalan maupun menyebrang, jalanan yang tidak layak seperti jalan yang berlubang, kerusakan kendaraan, kendaraan yang sudah tidak layak lagi pakai, pengendara yang tidak mematuhi rambu-rambu lalu lintas, dan masih banyak lagi yang menimbulkan masalah pelanggaran lalu lintas yang telah ditentukan pemerintah khususnya Dinas Perhubungan dan Kepolisian.

Kecepatan kendaraan saat melaju di jalan berbanding lurus dengan tingkat keparahan kecelakaan lalu lintas. Menurut WHO, rata-rata kenaikan kecepatan 1 $\mathrm{km} / \mathrm{jam}$ menyebabkan kenaikan risiko keparahan kecelakaan lalu lintas sebesar 4-5\% (Kutsiyah, 2011). Berdasarkan klasifikasi masa remaja menurut Depkes RI (2001), rentang usia siswa SMP berada pada masa remaja tengah yang merupakan masa peralihan dari masa anak menuju dewasa. Masa remaja merupakan tahap di mana terjadi perubahan fisik dan psikis yang berpengaruh pada pola pikir, sikap, dan pola perilaku. Remaja juga memiliki kecenderungan untuk melakukan perilaku menyimpang karena berbagai hal yang disenangi akan dilakukan oleh remaja tanpa mempertimbangkan untung rugi.

Salah satu contoh fenomena yang terjadi saat ini yaitu kecelakaan maut yang menewaskan empat orang terjadi di Jalan Magelang, Kecamatan Mlati, Kabupaten Sleman, Daerah Istimewa Yogyakarta, Sabtu (3/10/2020) dimana salah seorang pengemudi mobil masih remaja dan belum mengantongi SIM. Dari sini dapat diketahui bahwa masih banyak yang tidak memperhatikan aturan berkendara di jalan atau aturan lalu lintas sehingga menyebabkan kejadian yang tidak diinginkan seperti kecelakaan maut yang berdampak merenggut nyawa mereka. Salah satu aturan lalu lintas yang dilanggar dalam fenomena ini yaitu pengemudi yang tidak mengantongi SIM.

Tujuan dari penelitian ini adalah untuk mengetahui atau menganalisis: (1) faktor penyebab terjadinya pelanggaran lalu lintas dan (2) strategi yang dilakukan oleh SATLANTAS dalam mengurangi pelanggaran lalu lintas sehingga tercapainya masyarakat patuh hokum. Manfaat yang diharapkan diperoleh dari data penelitian ini adalah sebagai bahan literature dan sosialisasi dalam menambah pemahaman terhadap pembaca baik itu pengendara, pejalan kaki, atau masyarakat lainnya mengenai pentingnya tertib lalu lintas agar tidak terjadi pelanggaran peraturan lalu lintas baik disengaja maupun tidak disengaja serta mematuhi segala bentuk peraturan lalu lintas yang berlaku.

\section{METODE PENELITIAN}

Jenis penelitian yang di gunakan adalah jenis penelitian diskriptif, yaitu suatu penelitian yang dimaksudkan untuk memberikan gambaran tentang keadaan subyek dan/atau obyek penelitian sebagaimana adanya. Sumber data penelitian ini diambil melalui studi kepustakaan karena data tidak melulu bisa 


\begin{tabular}{|c|c|c|c|c|}
\hline JURNAL & \multirow{2}{*}{ VOLUME 3} & \multirow{2}{*}{ NOMOR 1 } & HALAMAN 75-85 & $\begin{array}{l}\text { ISSN 2655-8823 }(p) \\
\text { ISSN 2656-1786 }(e)\end{array}$ \\
\hline
\end{tabular}

didapat dari lapangan. Ada kalanya sumber data hanya bisa didapat dari perpustakaan atau dokumen-dokumen lain dalam bentuk tulisan, baik dari jurnal, buku maupun literatur yang lain. Studi kepustakaan diperlukan sebagai salah satu cara untuk memahami gejala-gejala baru atau permasalahan yang terjadi yang belum dapat dipahami, kemudian dengan studi kepustakaan ini akan dapat dipahami gejala atau masalah tersebut. Sehingga dalam mengatasi suatu gejala atau masalah yang terjadi, penulis dapat merumuskan konsep untuk menyelesaikan suatu permasalahan yang muncul.

\section{KAJIAN PUSTAKA \\ Remaja}

Remaja merupakan masa dimana peralihan dari masa anak-anak ke masa dewasa, yang telah meliputi semua perkembangan yang dialami sebagai persiapan memasuki masa dewasa. Perubahan perkembangan tersebut meliputi aspek fisik, psikis dan psikososial. Masa remaja merupakan salah satu periode dari perkembangan manusia. Remaja ialah masa perubahan atau peralihan dari anak-anak ke masa dewasa yang meliputi perubahan biologis, perubahan psikologis, dan perubahan sosial (Sofia \& Adiyanti, 2013).

\section{Pelanggaran Lalu Lintas}

Pengertian Lalu Lintas

Pengertian lalu lintas menurut Pasal 1 Undang-Undang Nomor 22 Tahun 2009 Tentang Lalu Lintas dan Angkutan Jalan didefinisikan sebagai gerak kendaraan dan orang di ruang lalu lintas jalan, sebagai prasarana yang diperuntukkan bagi gerak pindah kendaraan, orang, dan/atau barang yang berupa jalan dengan fasilitas pendukungnya.

Menurut Muhammad Ali, lalu lintas adalah berjalan, bolak balik, perjalanan di jalan. Ramdlon Naning juga menguraikan pengertian tentang lalu lintas yaitu gerak pindah manusia dengan atau tanpa alat penggerak dari satu tempat ke tempat lain. Sedangkan menurut Poerwodarminto bahwa lalu lintas adalah Perjalanan bolakbalik; Perihal perjalanan di jalan dan sebagainya; Berhubungan antara sebuah tempat.

Berdasarkan pengertian dan definisidefinisi di atas dapat diartikan bahwa lalu lintas ialah setiap hal yang berhubungan dengan sarana jalan umum sebagai sarana utama untuk tujuan yang ingin dicapai. Lalu lintas juga dapat diartikan sebagai hubungan antara manusia dengan atau tanpa disertai alat penggerak dari suatu tempat ke tempat lain dengan menggunakan jalan sebagai ruang geraknya.

\section{Pelanggaran Lalu Lintas}

Pelanggaran lalu lintas jalan adalah perbuatan atau tindakan yang bertentangan dengan ketentuan-ketentuan peraturan perundang-undangan lalu lintas (Ramdlon Naning). Pelanggaran yang dimaksud adalah pelanggaran yang sebagaimana diatur dalam Pasal 105 Undang-undang Nomor 22 Tahun 2009 yang berbunyi:

1. Berperilaku tertib dan/atau

2. Mencegah hal-hal yang dapat merintangi, membahayakan keamanan dan keselamatan lalu lintas dan angkutan jalan atau yang dapat menimbulkan kerusakan jalan.

Menurut Wirjono Prodjodikoro pengertian pelanggaran adalah "overtredingen" atau pelanggaran berarti suatu perbuatan yang melanggar sesuatu dan berhubungan dengan hukum, berarti tidak lain dari pada perbuatan melawan hukum. Sedangkan menurutt Bambang Poernomo mengemukakan bahwa pelanggaran adalah politis-on recht dan kejahatan adalah crimineel-on recht. Politis-on recht itu merupakan perbuatan yang tidak mentaati larangan atau keharusan yang telah ditentukan oleh penguasa negara. Sedangkan crimineel-on recht itu merupakan perbuatan yang 


\begin{tabular}{|c|c|c|c|c|}
\hline JURNAL & \multirow{2}{*}{ VOLUME 3} & \multirow{2}{*}{ NOMOR 1 } & HALAMAN 75-85 & $\begin{array}{l}\text { ISSN 2655-8823 }(p) \\
\text { ISSN 2656-1786 }(e)\end{array}$ \\
KOLABORASI RESOLUSI KONFLIK & HOLN
\end{tabular}

bertentangan dengan hukum. Dari berbagai definisi pelanggaran tersebut maka dapat diartikan bahwa unsur-unsur pelanggaran ialah:

1. Adanya perbuatan yang bertentangan dengan perundangundangan

2. Menimbulkan akibat hokum

Dari berbagai pengertian di atas dapat diartikan bahwa pelanggaran adalah suatu perbuatan atau tindakan yang bertentangan dengan ketentuan peraturan perundangundangan.

Berdasarkan dari definisi-definisi tentang pelanggaran dan pengertian lalu lintas di atas, maka dapat diartikan bahwa yang dimaksud dengan pelanggaran lalu lintas adalah suatu tindakan atau perbuatan yang dilakukan oleh seseorang yang mengemudikan kendaraan umum atau kendaraan bermotor juga pejalan kaki yang bertentangan dengan peraturan perundangundangan lalu lintas yang berlaku.

Faktor Penyebab Terjadinya Pelanggaran Lalu Lintas

Menurut Soedjono Soekanto, faktor peyebab terjadinya pelanggaran lalu lintas adalah:

1) Faktor Manusia

Biasanya disebabkan oleh pemakai jalan yang kurang disiplin dan memperhatikan kesadaran hukum, baik sebagai pengemudi, pemilik kendaraan, pejalan kaki, maupun pencari nafkah (supir). Adanya tingkah lalu sebagian dari pengemudi yang tidak takut melakukan pelanggaran karena adanya faktor-faktor yang menjaminnya seperti diselesaikan dengan jalan "atur damai" membuat para pelanggaran lalu lintas menyepelekan peraturan-peraturan yang berlaku berkaitan dengan lalu lintas.

2) Faktor Sarana Jalan

Sarana jalan sebagai penyebab terjadinya pelanggaran dan kecelakaan lalu lintas jalan antara lain disebabkan karena adanya pipa galian. Pipa galian ini bisa seperti galian pipa listrik, pipa air minum dan sebagainya yang kesemuanya itu dapat mengakibatkan terjadinya arus kemacetan. Selain dari adanya pipa galian, faktor lain dari sarana jalan ialah adanya jalan-jalan yang telah rusak dan mengakibatkan adanya genangan-genangan air ketika hujan turun. Genangan-genangan air ini biasanya membuat kemacetan juga sering menimbulkan adanya kecelakaan yang terjadi antar pengguna jalan.

3) Faktor Kendaraan

Kendaraan sebagai salah satu faktor penyebab terjadinya pelanggaran lalu lintas berkaitan erat dengan adanya perkembangan jenis kendaraan yang semakin pesat bersamaan dengan perkembangan teknologi pembuatan kendaraan, sehingga berbagai jenis dan jumlah kendaraan mampu diproduksi dalam jangka waktu yang relativ singkat. Pekembangan kendaraan yang semakin pesat ini apabila tidak diimbangi dengan perkembangan sarana jalan yang memadai, maka dapat menyebabkan kemacetan lalu lintas. Arus lalu lintas yang padat dapat menyebabkan terjadinya kejahatan seperti penjambretan, penodongan, pencopetan dan lain sebagainya. Pelanggaran lalu lintas yang sering terjadi dari faktor kendaraan adalah antara lain ban motor yang sudah gundul, lampu weser yang tidak berfungsi sebagaimana mestinya dan lain sebagainya.

4) Faktor Keadaan Alam (lingkungan)

Pelanggaran lalu lintas yang disebabkan karena faktor keadaan alam atau lingkungan biasanya terjadi dalam keadaan yang tidak terduga. Ketika hujan turun, maka pada umumnya semua kendaraan akan menambah laju kendaraannya sehingga pelanggaran lalu lintas akan sangat mungkin terjadi. Misalnya seseorang pengendara motor 


\begin{tabular}{|c|c|c|c|c|}
\hline JURNAL & \multirow{2}{*}{ VOLUME 3} & \multirow{2}{*}{ NOMOR 1 } & HALAMAN 75-85 & $\begin{array}{l}\text { ISSN 2655-8823 }(p) \\
\text { ISSN 2656-1786 }(e)\end{array}$ \\
KOLABORASI RESOLUSI KONFLIK & HOLN
\end{tabular}

yang takut terkena air hujan sehingga tidak segan-seganmemilih jalan pintas baik dengan melanggar rambu lalu lintas atau tetap mematuhi peraturan yang ada.

Menurut Haddon's Matrix, faktor lingkungan disini terbagi dalam tiga tahap diantaranya:

1) Pra-kecelakaan: guna untuk mencegah terjadinya kecelakaan,

2) Saat keceakaan: guna untuk pencegahan cedera, dan

3) Pasca-kecelakaan: guna mempertahankan hidup orang tersebut.

\section{Teori Kontruksi Sosial}

Teori yang digunakan dalam penelitian ini yaitu teori perspektif kontruksi sosial yang mana berfokus pada bagaimana manusia membangun makna dan sense of self atas kehidupan sosialnya melalui interaksi sosial. Manusia berinteraksi dengan satu sama lain dan lingkungannya karena adanya shared meanings \& understanding --> realitas yang terbentuk dan terus menerus terbentuk ulang selama adanya interaksi sosial. Tidak ada realita yang objektif dan benar, yang ada itu realita subjektif bersama (menekankan pada banyaknya realita sosial dan budaya, dan manusia serta lingkungannya merupakan proses yang dinamis).

Teori konstruksi sosial (social construction) Berger dan Lukmann merupakan teori sosiologi kontemporer yang berpijak pada sosiologi pengetahuan. Dalam teori ini terkandung pemahaman bahwa kenyataan dibangun secara sosial, serta kenyataan dan pengetahuan merupakan dua istilah kunci untuk memahaminya. Kenyataan adalah suatu kualitas yang terdapat dalam fenomenafenomena yang diakui memiliki keberadaan (being)-nya sendiri sehingga tidak tergantung kepada kehendak manusia; sedangkan pengetahuan adalah kepastian bahwa fenomen-fenomen itu nyata (real) dan memiliki karakteristik yang spesifik (Berger, 1990: 1).

Oleh karena konstruksi sosial merupakan sosiologi pengetahuan maka implikasinya harus menekuni pengetahuan yang ada dalam masyarakat dan sekaligus proses-proses yang membuat setiap perangkat pengetahuan yang ditetapkan sebagai kenyataan. Sosiologi pengetahuan harus menekuni apa saja yang dianggap sebagai pengetahuan dalam masyarakat

\section{HASIL DAN PEMBAHASAN \\ Bentuk Pelanggaran Lalu Lintas yang Dilakukan oleh Kaum Remaja}

Manusia sebagai pemakai jalan yaitu sebagai pejalan kaki dan pengendara kendaraan baik kendaraan bermotor maupun kendaraan tidak bermotor. Interaksi antara faktor Manusia, Kendaraan, Jalan dan Lingkungan sangat bergantung dari perilaku Manusia sebagai pengguna jalan menjadi hal yang paling dominan terhadap Kamseltibcar Lantas, hal ini sangat ditentukan oleh beberapa indikator yang membentuk sikap dan perilakunya di Jalan raya berupa mental, pengetahuan, dan keterampilan.

Bentuk-bentuk pelanggaran lalu lintas yang sering dilakukan oleh kalangan remaja khususnya pelajar diantaranya sebagai berikut:

1. Menggunakan jalan dengan cara yang dapat merintangi membahayakan ketertiban atau keamanan lalu lintas atau yang mungkin menimbulkan kerusakan pada jalan.

2. Mengemudikan kendaraan bermotor yang tidak dapat memperlihatkan surat ijin mengemudi (SIM), STNK, Surat Tanda Uji Kendaraan (STUJ) yang sah atau tanda bukti lainnya sesuai peraturan yang berlaku atau dapat memperlihatkan tetapi masa berlakunya sudah kadaluwarsa.

3. Membiarkan atau memperkenakan kendaraan bermotor dikemudikan 


\begin{tabular}{|c|c|c|c|c|}
\hline JURNAL & \multirow{2}{*}{ VOLUME 3} & \multirow{2}{*}{ NOMOR 1 } & HALAMAN 75-85 & $\begin{array}{l}\text { ISSN 2655-8823 }(p) \\
\text { ISSN 2656-1786 }(e)\end{array}$ \\
KOLABORASI RESOLUSI KONFLIK & ISS \\
\hline
\end{tabular}

oleh orang lain yang tidak memiliki SIM.

4. Tidak memenuhi ketentuan peraturan perundang-undangan lalu lintas jalan tentang penomoran, penerangan, peralatan, perlengkapan, pemuatan kendaraan dan syarat penggandengan dengan kendaraan lain.

5. Membiarkan kendaraan bermotor yang ada di jalan tanpa dilengkapi plat tanda nomor kendaraan yang syah, sesuai dengan surat tanda nomor kendaraan yang bersangkutan.

6. Pelanggaran terhadap perintah yang diberikan oleh petugas pengatur lalu lintas jalan, ramburambu atau tanda yang yang ada di permukaan jalan.

7. Pelanggaran terhadap ketentuanketentuan tentang ukuran dan muatan yang diijinkan, cara menaikkan dan menurunkan penumpang dan atau cara memuat dan membongkar barang.

Beberapa bentuk pelanggaran diatas sangat mengganggu kenyamanan dan keselamatan dalam berlau lintas yang berdampak pada :

- Tingginya angka kecelakaan lalu lintas baik pada persimpangan lampu lalu lintas maupun pada jalan raya;

- Keselamatan para pengendara dan para pejalan kaki menjadi terancam;

- Kemacetan lalu lintas akibat dari masyarakat yang enggan untuk berjalan kaki atau memanfaatkan sepeda ontel;

- Kebiasaan melanggar peraturan lalu lintas yang biasa kemudian menjadi budaya melanggar peraturan.

\section{Strategi yang Dikembangkan Satuan Lalu Lintas dalam Mengurangi Pelanggaran Lalu Lintas}

Salah satu strategi penegakan hukum khususnya bagian ketertiban lalu lintas adalah dengan melakukan pengendalian lalu lintas, pemakai jalan serta konsep penentu keselamatan lalu lintas, karena merupakan unsur yang menentukan dan penyebab terjadi atau tidaknya pelanggaran lalu lintas. Beberapa strategi yang didasarkan pada kebijaksanaan yang dikembangkan untuk mengurangi pelanggaran lalu lintas antara lain dengan:

1) Metode preventif (pencegahan)

Metode preventif adalah upaya-upaya yang ditujukan untuk mencegah terjadinya pelanggaran lalu lintas yang dalam bentuk kongkretnya berupa kegiatan penyuluhan lalu lintas, penjagaan tempat- tempat rawan, patroli, pengawalan, dan kegiatan lainnya. Garis besar strategi dengan metode preventif dapat disajikan di bawah ini:

a. Upaya pengaturan faktor jalan.

Karakteristik prasarana jalan akan mempengaruhi intensitas dan kualitas kemacetan dan pelanggaran lalu lintas, maka jaringan jalan pembangunannya harus disesuaikan dengan pola pemakaiannya yakni dibangun sesuai standart desain dan geometriknya.

b. Upaya pengaturan faktor kendaraan.

Faktor kendaraan juga sering membawa dampak tingginya intensitas dan kualitas pelanggaran lalu lintas. Untuk penanggulangannya kendaraan harus dirancang, diberi perlengkapan dan dirawat sebaikbaiknya, karena masing-masing peralatan kendaraan memiliki fungsi yang cukup penting untuk keselamatan di jalan. 


\begin{tabular}{|c|c|c|c|c|}
\hline JURNAL & \multirow{2}{*}{ VOLUME 3} & \multirow{2}{*}{ NOMOR 1 } & HALAMAN 75-85 & $\begin{array}{l}\text { ISSN 2655-8823 }(p) \\
\text { ISSN 2656-1786 }(e)\end{array}$ \\
KOLABORASI RESOLUSI KONFLIK & HOLN
\end{tabular}

c. Upaya pengaturan sistem lalu lintas.

Pengaturan sistem lalu lintas untuk pengendalian umum pemakai jalan, kendaraan, dan interaksi dalam sistem lalu lintas. Keseluruhan ketentuan lalu lintas bersifat rasional, baik mengenai fasilitas dan pengawasan pemakaian sarana lalu lintas dan penegakan hukum bagi pelanggarnya.

d. Pengaturan faktor manusia.

Manusia merupakan faktor utama dan elemen paling besar Pengaruhnya dan paling kritis dalam sistem lalu lintas, karena ketrampilan manusia sulit untuk ditingkatkan dalam tempo singkat.

2) Metode represif (penanggulangan)

Metode represif merupakan metode dalam rangka menanggulangi pelanggaran lalu lintas pada hakekatnya upaya terakhir dengan penerapan upaya paksa. Bentuk-bentuk dari metode represif ini dijelaskan sebagai berikut:

a. Stasioner

Penanggulangan pelanggaran lalu lintas dimulai dari kelengkapan surat-surat yang berupa Surat Ijin Mengemudi (SIM) serta Surat Tanda Nomor Kendaraan (STNK). Melalui penyuluhan- penyuluhan serta himbauan-himbauan dalam metode preventif di atas telah dianjurkan kepada para pengemudi agar memiliki dan selalu membawa Surat Ijin Mengemudi pada saat berlalu lintas di jalan raya.

b. Haunting System

Sesuai dengan Surat Telegram Kapolda Jateng No: 402/11/2012 pada tanggal 13 Februari 2012 bahwa pelaksanaan penindakan pelanggaran lalu lintas di jalan raya dengan melalui haunting system (sistem pengawasan). Dengan dilakukannya pengawasan tersebut diharapkan para pengemudi kendaraan bermotor tidak menyalahi aturan-aturan dalam berlalu lintas dan tertib dalam berlalu lintas sesuai aturan-aturan yang ada.

Sesuai dengan Surat Telegram Kapolda Jateng No: 402/11/2012 pada tanggal 13 Februari 2012 serta UndangUndang No. 22 tahun 2009 tentang Lalu Lintas dan Angkutan jalan, yaitu sebagai berikut:

(1) Pelanggaran zebra cross dan stop line, (Pasal 287(1) jo 106(4)a dan 106(4)b)

(2) Pelanggaran muatan dan dimensi, (Pasal 307 jo 169(1))

(3) Pelanggaran lawan arus, terobos jalur lawan (control low), (Pasal 287(1) jo 106(4)a dan 106(4)b)

(4) Pelanggaran berhenti di persimpangan, (Pasal 302 jo 126)

(5) Pelanggaran terhadap angkutan umum yang mengangkut penumpang dengan bergelantungan, (Pasal $300 \mathrm{c}$ jo 124(1))

(6) Pelanggaran terhadap pengemudi roda dua yang berboncengan lebih dari 1 (satu) orang, (Pasal 292 jo 106(9))

(7) Pelanggaran tidak menggunakan helm SNI bagi pengendara maupun pembonceng/penumpang, (Pasal 291(1),(2) jo 106(8))

(8) Pelanggaran memutar arah pada rambu larangan (Pasal 287(1) jo 106(4)a)

(9) Pelanggaran berhenti di jembatan, (Pasal 287(1) jo 106(4)e)

\section{Penegakan Hukum Lalu Lintas dalam Rangka Tercapainya Masyarakat Patuh Hukum}

Suatu pameo klasik memberikan alternative yang dilematis, antara materi hokum yang bagus dijalankan oleh aparat penegak hukum yang jelek, atau materi hukum yang cacat dijalankan oleh aparat penegak hukum yang bagus, maka akan 


\begin{tabular}{|c|c|c|c|c|}
\hline JURNAL & \multirow{2}{*}{ VOLUME 3} & \multirow{2}{*}{ NOMOR 1 } & HALAMAN 75-85 & $\begin{array}{l}\text { ISSN 2655-8823 }(p) \\
\text { ISSN 2656-1786 }(e)\end{array}$ \\
KOLABORASI RESOLUSI KONFLIK & HOLN
\end{tabular}

terpilih alternatif kedua, karena output nya akan lebih baik daripada memilih alternatif pertama. Kondisi idealnya adalah baik materi hukum maupun aparat penegak hukumnya bagus. Hal ini menunjukkan pentingnya "Kualitas moral dan etika aparat penegak hukum" khususnya Polri dan PPNS yang diberi wewenang untuk melakukan dan mengambil tindakan dalam rangka penegakan hukum akan berdampak pada kinerja yang profesional. Kualitas moral dan etika penegak hukum yang tinggi guna terwujudnya kinerja penegak hukum yang baik.

Kenyataan dalam proses ini penyelenggaraan penegakan hukum dibidang lalu lintas, bahwa masing-masing aparat belum bekerja secara profesional, hal ini bisa dilihat dari beberapa hal seperti penerapan hukum tidak diaksanakan sebagaimana mestinya; penjatuhan vonis oleh hakim terhadap pelaku pelanggaran lalu lintas tidak mengindahkan ancaman pidana sehingga tidak memberikan efek jera bagi pelanggar yang dihukum; Sistem tilang dan mekanisme proses peradilan terhadap pelanggaran lalu lintas tidak dilaksanakan sebagaimana mekanisme sidang pengadilan yang benar, bahkan terkesan asal-asalan; Konsistensi dalam pelaksanaan penegakan hukum belum diproyeksikan pada upaya peningkatan keselamatan lalu lintas dan kepatuhan hukum masyarakat walaupun telah ada konsep tentang penindakan dengan pola System Potensial Point Target (SPPT) dan pelaksanaan kawasan tertib lalu lintas (KTL); Penerapan Perda yang bertentangan dengan ketentuan hirarki perundang-undangan; Pemanfaatan teknologi dan laboratorium forensik dalam bidang pengungkapan kasus kecelakaan lalu lintas utamanya kasus-kasus kecelakaan yang menonjol belum dilaksanakan.

Bukan hanya persoalan penyelenggaraan penegakan hukum dibidang lalu lintas yang belum bekerja secara profesional, tetapi sikap penegak hokum sendiri sangat berpengaruh seperti:

a. Lemahnya etika moral dan profesionalisme sebagai aparat penegak hukum serta sikap arogansi yang masih melekat dalam melaksanakan tugas penegakan hukum.

b. Banyaknya penyimpangan yang dilakukan dengan cara melampaui batas wewenang, pungli, bertindak kasar dan tidak mencerminkan sebagai sosok pelindung, pengayom dan pelayan masyarakat.

c. Lemahnya koordinasi antar aparat penegak hukum baik sesama aparat penegak hukum di jalan maupun dengan unsur Criminal Justice System (CJS).

d. Pelaksanaan penegakan hukum oleh penyidik pegawai negeri sipil (PPNS) Departemen Perhubungan / LLAJR terhadap pelanggaran yang sesuai dengan kewenangannya tidak dilaksanakan sesuai dengan ketentuan yang ada.

e. Penanganan dan pengelolaan trayek angkutan umum baik angkutan umum antar propinsi maupun trayek didalam satu propinsi sering menimbulkan terjadinya protes akibat adanya tumpang tindih perijinan trayek serta tidak rasionalnya pemberian trayek pada daerah tertentu dengan dalih otonomi daerah.

f. Traffic Education belum dilaksanakan dengan baik dan kontinyu.

g. Proses pemberian surat ijian mengemudi (SIM) tidak dilaksanakan sesuai dengan mekanisme dan prosedur yang ada.

Disamping itu, sarana dan prasarana yang mendukung terlaksananya penegakan hukum di bidang lalu lintas sangat terbatas. Seperti Perlengkapan jalan (rambu-rambu, marka jalan, penerangan 


\begin{tabular}{|c|c|c|c|c|}
\hline JURNAL & \multirow{2}{*}{ VOLUME 3} & \multirow{2}{*}{ NOMOR 1 } & HALAMAN 75-85 & $\begin{array}{l}\text { ISSN 2655-8823 }(p) \\
\text { ISSN 2656-1786 }(e)\end{array}$ \\
KOLABORASI RESOLUSI KONFLIK & HOLN
\end{tabular}

jalan dan tanda-tanda lalu lintas lain dirasakan masih sangat kurang); Mobilitas aparat penegak hukum yang tidak mengimbangi hakekat ancaman; Alat teknologi yang dapat dimanfaatkan untuk tugas penegak hukum, belum bisa dioperasionalkan secara yuridis, serta tidak berfungsinya jalan sebagaimana mana mestinya, akibatnya penggunaan untuk kaki lima, parkir pada badan jalan, bangunan pada daerah manfaat jalan dan sebagainya.

\section{KESIMPULAN DAN SARAN Kesimpulan}

Berdasarkan hasil penelitian dan pembahasan, faktor yang melatarbelakangi pelanggaran lalu lintas disebabkan oleh manusia itu sendiri karena kurangnya kesadaran akan peraturan berlalu lintas manusia sebagai pemakai jalan yaitu sebagai pejalan kaki dan pengendara kendaraan baik kendaraan bermotor maupun kendaraan tidak bermotor.

Bentuk-bentuk pelanggaran lalu lintas yang sering dilakukan oleh kalangan remaja khususnya pelajar diantaranya : Menggunakan jalan dengan cara yang dapat merintangi membahayakan ketertiban atau keamanan lalu lintas atau yang mungkin menimbulkan kerusakan pada jalan; Mengemudikan kendaraan bermotor yang tidak dapat memperlihatkan surat ijin mengemudi (SIM), STNK, Surat Tanda Uji Kendaraan (STUJ) yang sah atau tanda bukti lainnya sesuai peraturan yang berlaku atau dapat memperlihatkan tetapi masa berlakunya sudah kadaluwarsa; Membiarkan atau memperkenakan kendaraan bermotor dikemudikan oleh orang lain yang tidak memiliki SIM; Tidak memenuhi ketentuan peraturan perundang-undangan lalu lintas; Membiarkan kendaraan bermotor yang ada di jalan tanpa dilengkapi plat tanda nomor kendaraan yang sah; Pelanggaran terhadap perintah yang diberikan oleh petugas pengatur lalu lintas jalan, rambu-rambu atau tanda yang yang ada di permukaan jalan; Pelanggaran terhadap ketentuanketentuan tentang ukuran dan muatan yang diijinkan, cara menaikkan dan menurunkan penumpang dan atau cara memuat dan membongkar barang.

Beberapa bentuk pelanggaran diatas sangat mengganggu kenyamanan dan keselamatan dalam berlau lintas yang berdampak pada Tingginya angka kecelakaan lalu lintas baik pada persimpangan lampu lalu lintas maupun pada jalan raya; Keselamatan para pengendara dan para pejalan kaki menjadi terancam; Kemacetan lalu lintas akibat dari masyarakat yang enggan untuk berjalan kaki atau memanfaatkan sepeda ontel; Kebiasaan melanggar peraturan lalu lintas yang biasa kemudian menjadi budaya melanggar peraturan.

Beberapa strategi yang didasarkan pada kebijaksanaan yang dikembangkan untuk mengurangi pelanggaran lalu lintas antara lain dengan:

1) Metode preventif (pencegahan)

a. Upaya pengaturan faktor jalan

b. Upaya pengaturan faktor kendaraan

c. Upaya pengaturan sistem lalu lintas

d. Pengaturan faktor manusia

2) Metode represif (penanggulangan)

a. Stasioner

b. Haunting System

Penegakan hukum lalu lintas dalam rangka tercapainya masyarakat patuh hokum belum bekerja secara profesional dikarenakan penerapan hukum tidak diaksanakan sebagaimana mestinya, sikap penegak hokum yang belum profesional, serta sarana dan prasarana yang terbatas untuk mendukung terlaksananya penegakan hukum.

\section{Saran}

Berdasarkan kesimpulan yang telah dijelaskan di atas, maka saran yang dapat diberikan dalam penelitian ini adalah:

a) Bagi masyarakat khususnya remaja agar dapat patuh terhadap 


\begin{tabular}{|c|c|c|c|c|}
\hline JURNAL & \multirow{2}{*}{ VOLUME 3} & \multirow{2}{*}{ NOMOR 1 } & HALAMAN 75-85 & $\begin{array}{l}\text { ISSN 2655-8823 }(p) \\
\text { ISSN 2656-1786 }(e)\end{array}$ \\
KOLABORASI RESOLUSI KONFLIK & HOLN
\end{tabular}

peraturun peraturan lalu lintas yang berlaku seperti melengkapi persyaratan berkendara dan menaati rambu-rambu lalu lintas yang ada hal tersebut merupakan salah satu perwujudan taat hukum yang harus dilakukan oleh kita selaku warga Negara yang baik,

b) Bagi aparat kepolisian lebih profesional dalam bertufgas dan menyebar luaskan tentang peraturan atau undang undang lalu lintas yang berlaku dengan mengadakan sosialisasi ke desa desa sebagai wujud bakti terhadap Negara menindak pelaku pelanggaran sesuai prosedur yang ada dan tidak menerima suap.

\section{DAFTAR PUSTAKA}

Anggrasena, B. (2010). Strategi Penegakan Hukum dalam Rangka Meningkatkan Keselamatan Lalu Lintas dan Mewujudkan Masyarakat Patuh Hukum. 20.

Anisarida, A. A., \& Santosa, W. (2019). Korban Kecelakaan Lalu Lintas Sepeda Motor Di Kota Bandung. Jurnal HPJI, 5(2), 129-136.

Anugrahanto, N. C. (2020). Kecelakaan Menewaskan Empat Orang, Pengemudi Mobil Masih Remaja. https://www.kompas.id/baca/nusantara /2020/10/03/empat-orang-tewasdalam-kecelakaan-lalu-lintas-di-jalanmagelang-pengemudi-masih-remaja/ $(30 / 12 / 2020)$

Bolla, M. E., Messah, Y. A., \& Koreh, M. M. B. (2013). Analisis Daerah Rawan Kecelakaan Lalu Lintas (Studi Kasus Ruas Jalan Timur Raya Kota Kupang). Jurnal Teknik Sipil, II(2), 147-156.

Darmansyah, F., \& Prasetyanto, D. (2019). Strategi Penegakan Hukum Dalam Meningkatkan Keselamatan Lalu Lintas Di Kota Bandung. Jurnal Transportasi, 19(1), 11-20.

Djaja, S., Widyastuti, R., Tobing, K., Lasut, D., \& Irianto, J. (2016).
GAMBARAN KECELAKAAN LALU LINTAS DI INDONESIA , TAHUN 2010-2014 Description of Traffic Accident in Indonesia, Year 20102014. 2007, 30-42.

Gunawan, D. N. (2019). KEMACETAN LALU LINTAS KENDARAAN BERMOTOR DAN PENGARUHNYA TERHADAP PEREKONOMIAN KOTA-KOTA BESAR DI INDONESIA.

Hidayati, A., \& Hendrati, L. Y. (2016). Analisis Risiko Kecelakaan Lalu Lintas Berdasar Pengetahuan, Penggunaan Jalur, dan Kecepatan Berkendara. Jurnal Berkala Epidemiology, 4(2), 275-287.

Junef, M. (2014). Perilaku Masyarakat Terhadap Operasi Bukti Pelanggaran ( Tilang ) Dalam Berlalu Lintas. WIDYA Yustisia, 1(1), 52-60.

Labe, Anjari. (2017). Teknik Lalu Lintas Masalah Transfortasi "Pelanggaran Lalu Lintas". http://masalahtransportasi.blogspot.co $\underline{m} / ? m=1(21 / 10 / 2020)$

Manuaba, I. B. P. (2008). Memahami Teori Konstruksi Sosial. Masyarakat, Kebudayaan Dan Politik, 21(3), 221230.

Ngangi, C. R. (2011). Konstruksi Sosial dalam Realitas Sosial. AgriSosioekonomi, 7(2), 1-4.

Poerwadarminta. (1993). Kamus Besar Bahasa Indonesia, Op.Cit.,hlm. 55.

Prodjodikoro, Wirjono. (2003). Asas-asas Hukum Pidana. Bandung:Refika Aditama, hlm.33.

Rakhmani, F. (2013). Kepatuhan Remaja dalam berlalu Lintas. Sociodev, 2(1), $1-7$.

Remincel. (2019). DIMENSI HUKUM PELANGGARAN KECELAKAAN LALU DAN ANGKUTAN JALAN LINTAS DI INDONESIA. Jurnal Ensikopedia Social Review, 2(5), 55.

Rismawan, E. (2009). FAKTOR PENYEBAB PELANGGARAN LALU LINTAS OLEH PENGENDARA SEPEDA MOTOR. 1-124. 


\begin{tabular}{|c|c|c|c|c|}
\hline JURNAL & \multirow{2}{*}{ VOLUME 3} & \multirow{2}{*}{ NOMOR 1 } & HALAMAN 75-85 & $\begin{array}{l}\text { ISSN 2655-8823 }(p) \\
\text { ISSN 2656-1786 }(e)\end{array}$ \\
KOLABORASI RESOLUSI KONFLIK & HOLN
\end{tabular}

Saraswati, E. (2012). STRATEGI SATUAN LALU LINTAS DALAM MENGURANGI PELANGGARAN LALU LINTAS DI WILAYAH HUKUM POLRESTA SURAKARTA. 1-17.

Sari, R. R., Budiarsi, K., \& Maulana, M. S. (2018). Karakteristik Kecelakaan Jalan Soekarno Hatta Kota Bandung dengan Pendekatan "5W+1H". Potensi : Jurnal Sipil Politeknik, 20(2), 111.

Sarmini, A. (2019). Kualitas Pelayanan Surat Izin Mengemudi (SIM) Pada Kantor Satuan Lalu Lintas Polres Karimun. Soumatera Law Review, 2(2), 12.

Sarry, Y. P., \& Widodo, H. (2014). Upaya Polisi Lalu Lintas Dalam Meningkatkan Kedisiplinan Berlalu Lintas Pengendara Bermotor (Studi Deskriptif Terhadap Program Kanalisasi Lajur Kiri Pada Satlantas Polrestabes Surabaya). Kajian Moral Dan Kewarganegaraan, 2(2), 564 578.

Sibarani, S. (2016). Pelanggaran Peraturan Lalu Lintas Oleh Pengendara Sepeda Motor Roda Dua di Wilayah Polisi Sektor Ujung Batu Kabupaten Rokan Hulu. Jurnal Online Mahasiswa, 3(2), $1-15$.

Suhendra, A. D., Asworowati, R. D., \& Ismawati, T. (2020). PEMAHAMAN MASYARAKAT TERHADAP LALU

$\begin{array}{lr}\text { LINTAS DITINJAU } & \text { DARI } \\ \text { PEMAKAIAN } & \text { ALAT } \\ \text { KESELAMATAN } & \text { SAAT } \\ \text { BERKENDARA ( STUDI KASUS DI } \\ \text { DESA KARAGANOM KLATEN } \\ \text { UTARA). Akrab Juara, 5(1), } \begin{array}{r}\text { 1-65. } \\ \text { from }\end{array} \\ \begin{array}{lr}\text { Retrieved http://www.akrabjuara.com/index.php/ } \\ \text { akrabjuara/article/view/919 }\end{array}\end{array}$

Sulaiman, A. (2016). Memahami Teori Konstruksi Sosial Peter L. Berger. Society, 4(1), 15-22.

Tahir, A. (2006). Studi penyebab kecelakaan lalu lintas di kota surabaya. Teknik Sipil, 1-9.

Yassin, G. (2020). PENEGAKAN HUKUM KECELAKAAN LALU LINTAS AKIBAT JALAN RUSAK. Gorontalo Law Review, 3(2), 122-136.

Yudanto, A. Y., Apriyadi, M., \& Sanjaya, K. (2013). Optimalisasi Lampu Lalu Lintas dengan Fuzzy Logic. Jurnal ULTIMATICS, 5(2), 58-62.

Yuningsih, A. (2006). Implementasi Teori Konstruksi Sosial dalam Penelitian Public Relations. Mediator: Jurnal Komunikasi, 7(1), 59-70.

Yuwono, S., \& Soviana, E. (2010). KAMPANYE KESELAMATAN BERKENDARA : PENGARUHNYA TERHADAP KEDISIPLINAN DALAM BERLALU LINTAS. Jurnal Ilmiah Berkala Psikologi, 12, 148-153. 